\title{
Collective Identity for Societal Building in the Light of the Teachings of Iqbal
}

\author{
Javed Y. Uppal ${ }^{1, *}$ \\ ${ }^{1}$ Chairman Pakistan Foundation for the Advancement of Engineering and Technology, Chairman Engineering Project \\ Development Consultants, and President, Institution of Engineers, Pakistan
}

*Correspondence: 1-A Aibeck Block, Garden Town, Lahore, Pakistan. Tel: 92-300-410-7717. E-mail: javed.uppal@gmail.com

Received: January 3, 2022 Accepted: January 13, 2022 Online Published: January 20, 2022

doi:10.5430/wjss.v9n1p26 URL: https://doi.org/10.5430/wjss.v9n1p26

\begin{abstract}
This paper attempts to emphasize the role of collective identity in a group or community in the societal building in the light of the teachings of the poet Iqbal. People need to change their focus from personal-selves to a collective-self. It is described as to how healthier people are the need of the moneyed class. They are part of the stakeholders in any societal movement. The paper describes how to involve their interest. Outreach is easier these days because of digital instruments. A toolkit has been developed following which the individual selves can be mobilized together into a collective self, for the societal building. A few case studies are referred where collective identity among stakeholders is studied: in a renovation project environment in Finland, in management environment in Norway, and spiritual workforce environment in the US.
\end{abstract}

Keywords: personal identity, collective identity, societal building, stakeholders, toolkit

\section{Introduction}

\subsection{Collective Identity}

Tajfel and Turner (2004) have demonstrated that there are two kinds of self-concept: personal identity and social identity. In American references, the social identity is called the collective identity. A scale has been constructed which measures the social or collective identity. There are four sub-scales in it; Membership esteem, Public collective self-esteem, Private collective self-esteem, and Importance to identity.

\subsection{Collective Identity and Man's Exploitative Nature-the Greatest Hurdle in its Development}

Collective identity is the common definition of a community that develops from its peoples' common interests, experiences, and aspirations. Collective identity is a great force in all social movements. Yet, much of problem faced in its development, is due to the exploitative nature of some of the highly egotistic people. For the emergence of a collective identity, the egotistic energies should be directed not merely towards the 'gains for the few', but towards the gains of 'everybody' around. Wisman, Jon. (2018).

The acts of the people in a community should be aimed to 'improve' the plight of the people around and not to 'diminish' it. The behavior should be 'exo-genic' meaning energy emitting and not 'endo-genic' meaning energy absorbing. Gustavo Rohenkohl, Jennifer T. Coull, and Anna C. Nobre, (2011).

\section{Iqbal's Teachings}

\subsection{Iqbal's Call to Channelize the Immense Powers of the Inner Self towards Humanity}

Iqbal was a poet, philosopher and a leader who lived in the days of British Rule in the subcontinent of India from 1877 to 1938. Among the poetic works published in the local language of Urdu are, Baal-e- Jibril (the Wings of Jibril) in 1935, and eleven years after his first book Baang-e- Daara (Sound of Bells of Carevan) in1924. Shayari, Urdu. (2018). His poetic works in Persian language are: 1915 Israr-e-Khudi, 1918 Ramooz-e Bekhudi, 1924 Payyam-e 
Mashriq, 1927 Zaboor-e Ajam 1932 Javed Nama and 1938 Armaghan-e Hijaz (Post humus).

In English language, he delivered lectures in 1930-34 in Madras, Hyderabad, Aligarh in India and in London (UK), which have been published under the title: Reconstruction of religious thoughts in Islam. Iqbal addressed to the immense powers of the inner self, that man possessed, to bring about significant societal change. No doubt the teachings of Iqbal serve as a great change maker.

\subsection{Iqbal's Promise to Himself on His Arrival in UK}

In 1905, he traveled from Bombay to Trinity College Cambridge, and obtained the Bachelor's degree in1906. In the same year, he was called to the Bar as Barrister from Lincoln's Inn. In 1907, he moved to Heidelberg, at Ludwig Maximillian's University of Munich, from where he obtained a PhD in 1908 on 'The Development of Metaphysics in Persia' within his short stay in Munich of 4 months. In 1908 he taught Arabic at University College London.

Arriving at Kings Cross railway station in 1905, Iqbal wrote the following verses, which describe his then determined promise to himself:

Tu Abhi Reh Guzr Mein Hai, Qaid-e-Maqam Se Guzr

Misr-o-Hijaz Se Guzr, Paras-o-Shaam Se Guzr

(Your journey is not ended yet, do not be captivated from the charms of the place; Pass through the realms of time and space, East or West.)

Jis Ka Amal Hai Be-Gharz, Uss Ki Jaza Kuch Aur Hai

Hoor-o-Khiyaam Se Guzr, Badah-o-Jaam Se Guzr

(Your objectives are much higher and selfless; You are not to get involved in worldly matters: wine or women.)

\section{Garcheh Hai Dilkusha Bohat Husn-e-Farang Ki Bahar}

Taeerik-e-Buland Baal, Dana-o-Daam Se Guzr

(No doubt, the beauty and comforts in the West are heart attractive; You are on a much higher cause here, do not get enchanted by any enticements or offerings.) (Baal-e Jibril 025)

\subsection{Impact of Israr-e Khudi in Britain}

In Britain, he wrote:

Makan Fani, Makeen Ani, Azal, Tera, Abad Tera

\section{Khuda Ka Akhiri Pegham Hai Tu, Javidan Tu Hai}

(The habitations around are temporary, the inhabitants are temporary, but what you are carrying is a message of God, Islam. The message is the final one and is eternal.)

When asked, what was the purpose of his coming to Britain? Iqbal replied, 'to introduce Islam in Britain'. His 'Israr-e Khudi' of 1915, translated by Professor Reynold Nicholson (1920), even reviewed in the famous British science journal 'Nature' (Vol 109, 370-371, 23 March 1922), Zafar Iqbal (2004), and thus introduced in Britain, generated a huge stir, and created the movement towards the Welfare State in Britain. Iqbal was awarded the title of Sir in 1922. The steps towards establishment of the Welfare State in Britain, are seen in terms of:

1925 Neville Chamberlain's ‘Widows, Orphans and Old Age Contributions Act;

1935 Social Security Act (known as Public Assistance) and

1941 Beverage's 'Terms of British Welfare State'. Wikipedia. (2022).

\subsection{Change of Focus from Individual Self to Collective Self}

While Britain benefitted from Iqbal's teachings in the way of a movement converting itself into a true 'Welfare' state, the Muslims of the Indian Subcontinent benefitted from Iqbal's teachings in the way of a change in mindset from an accepted subservient minority to a free independent state Pakistan in 1947. Sara Rashid. (2019). Iqbal fills hearts with selflessness and pure dedication to love and accommodation for others. He teaches to rise above selfish greed and serve the needs of all.

Tu Hoa Gar Kam Ayar, Mein Hoa Gar Kam Ayar; 
Maut Hai Teri Barat, Maut Hai Meri Barat.

(The ruthless cunningness has unfortunately become the order of the day. If you are less cunning, you are gone. If I am less cunning, I am gone.)

Terey Rouz-o Shab Ki, Aur Haqiqat Hai Kiya;

Aik Zamaney Ki Rouw, Jis Mein Din Hai Na Raat.

(In today's rat race, worthless are your days and nights as they are just being swept away with the passing current of time, signs and relics.)

Ani-o Fani Tumam, Maujza Hai Hunur;

Kar-e Jahan Be-Sabat, Kar-e Jahah Be-Sabat.

(And all those masterpieces of technology collapse within no time, because these are created with selfish pursuits, and not with spirit of humanity.)

Awaal-o Akhar Fana, Baatan-o Zahir Fana;

Naqsh-e Kuhun Ho Keh Nau, Manzil-e Akhar Fana.

(All things vanish, whether in the beginning or in the end; all things vanish, whether they are visible or hidden; all things vanish whether they are new or old; Death is the destiny for all.)

\section{Hai Magar Uss Naqsh Meib, Rnag-e Sabat-o Douam;}

Ho Kiya Jis Ko Kissi, Mard-e Khuda Ne Tumam.

(But there is one kind of sign that has permanency; There is one kind of thing, that has sustainability, It is that which is made by true men of God.)

\section{Mard-e Khuda Ka Aml, Ishq Se Sahib Farugh;}

Ishq Hai Asl-e Hayat, Maut Hai, Uss Par Haram.

(The act performed by the true men of God, is facilitated by Ishq; a state of high degree of devotion). Ishq is the real life. Death does not come near it. Things done passionately for the good of everyone around go sustainable for ever.)

\subsection{Some Real Time Examples of Fully Devoted Personalities}

Mother Teresa (1910 - 1997), was a Roman Catholic nun. She served terminally ill and abandoned poor people in Calcutta, and healed them with her personal love and care. Her model was greatly replicated and was a success. She was awarded the Nobel Peace Prize in 1979 for her selfless service to people. Meg Greene. (2004).

Abdul Sattar Edhi was a Pakistani philanthropist, ascetic, and humanitarian who founded the Edhi Foundation, which runs the world's largest volunteer ambulance network, along with homeless shelters, animal shelter, rehab centers, and orphanages across Pakistan. Usama Khilji, Abdul Sattar Edhi. (2016).

Hakeem Muhammad Saeed was a Pakistani medical researcher, scholar, and philanthropist. He also served as governor of Sindh Province from 1993 until 1994. Hakeem Saeed was one of Pakistan's most prominent medical researchers in the field of Eastern medicines. Authored more than 200 books. Established Hamdard Foundation, and World Cultural Council. Hakeem Abdul Hameed. (2012).

\subsection{Selfish Pursuits}

Regarding the selfish pursuits that people are engaged in day and night, Iqbal writes:

Surat-e Shamsheer Hai Dast-e Qaza Mein Qaum;

Karti Hai Jo Har Zaman Apne Aml Ka Sisab;

Naqsh Hein Sab Na Tumam Khoon-e Jigar Ke Beghair;

Naghma Hai Sauda-e Khaam, Khoon-e Jigar Ke Beghair;

(Counting selfish gains every minute is killing us. Only passionate sense of giving for humanity has permanency) 


\subsection{People Matter, Everyone Matters}

Regarding the power of ordinary people, which many are not even aware of, Iqbal writes:

Afrad Ke Hathoun Mein Hai, Aqwaam Ki Taqdeer;

Har Fard Hai Millat Ke Muqadar Ka Sitara;

(It is the individuals who determine the fate of a nation.)

Do not just sit back and wait. Take things in your own hands. Team up with who are influential and resourceful. Convince them. Do whatever possibly you can.

\section{Wellbeing of People}

\subsection{Wellbeing of the People}

Wellbeing of the people is a state in which the sum total of the physical, psychological and spiritual needs of the people at large are satisfied. This is the only way to secure a prosperous World. Rachel Dodge, Annette P. Daly, Jan Huyton, Lalage Dorothy Sanders. (2012).

Regarding making the rise of the ordinary down trodden and forgotten people to secure a living for themselves, Iqbal writes:

\section{Ishq Ko Faryad Lazim Thhi So Wo Bhi Ho Chki;}

Abb Zara Dil Tham Kar Faryad KI Tabeer Dekh;

Tu Nai Dekha Satwat-e Darya Ka Arooj;

Mauj-e Muztar Kiss Tarha Banti Hai Abb Zanjeer Deth.

(The Ishq- fully devoted passion has made its appeal, now hold your breath and see the effect. You have seen the wholesome rise of the elite in the past, now you see how anguished ordinary people are rescued)

\section{Apni Khakastar Sumandar Ko Hai Saman-e Wajood;}

Mar Ke Phir Hota Hai Paida, Ye Jahan-e Pir DEth;

Khoul Kar Ankhain Meray Aina-e Guftar Main;

Anai Waley Daur Ki, Halki Si Ik Tasweer Deth.

(The vast dry wasteland is now looking forward to means its existence. The old long time died world is taking breath again. Open your eyes, and see in the mirror of my utterings, the times that are now soon coming)

\subsection{China's People's Mobilization}

With the built up of tremendous collective identity in China, the process of multiplication of disposable income in China, (700 percent between 2000 and 2020) was carried out by mobilization of population. Migration took place of people from western regions to coastal regions. See Fig-1. Textor, C. (2022). The living standards in China's both urban and rural areas have improved significantly over the past 20 years.

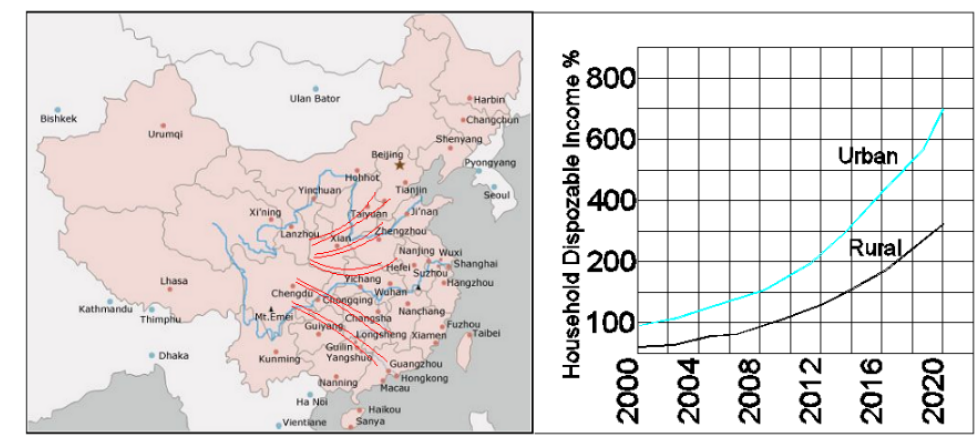

Figure 1. China Multiplication in Disposable Income on account of Mobilization of Workforce 
The urban population in China has crossed its rural population for the first time in 2011, and is continuously on the increase. Although, the remote, rural areas are still among the poorest areas, but greatest priority is being given to their poverty alleviation, plus the measures are being taken on relocation and job placement.

Regarding the Chinese phenomenon, Iqbal prophesized their rise, in these words, even before anyone could imagine: Giran Khuab Chini Sambhalney Lagae;

Hamala Se Chashme Ubalne Lagai

(Sulken sleepy Chinese are now getting wake up. The Himalayas are bursting with springs of sweet water)

China has now become economic world power mainly because it has turned its colossal population to healthy productive work force.

\subsection{Message to the Resourceful People}

The resourceful persons cannot restrict themselves to their conventional roles of money making. They have to set themselves to address the plight of the impoverished populations The impoverished populations are the backbone of workforce. The resourceful people so equipped and targeted can network with community organizations to out reach right down to the bottom lines and bring about the change. Reem Rahman, Kris Herbst, and Patrice Mobley. (2016).

\section{$3.4 T D C$ and TLC}

The resourceful people practice 'TDC' towards the impoverished people, that means thinly disguised contempt. They need to practice TLC i.e. tender, love and care. Refer Brown Stewart. (1987)., and Kevin David Kendrick, Simon Robinson. (1987). The resourceful people need to invest into the means to improve the plight of the impoverished people. It will automatically bring return to their investment in shape of ease of doing business, increase in productivity and safeguard against security hazards.

\subsection{Societal Change Requires Change in Our Inner Selves}

How does a societal change take place? What are the examples of the personalities who have been the instrument of change. Who are the personalities that remained uncontroversial even after their demise and thus their existence has been long lasting?

Societal change demands sacrifices from people, and we know that these personalities did make great sacrifices. Let us listen to them what they say. See what Iqbal says:

Teri Khudi Mein Agar Inqalab Ho Paida;

\section{Ajab Nahin He Keh Ye Charsoo Badal Jai.}

(You need to revolutionize your inner self; the way you perceive things, the way you think and the way you build your attitudes. It will be no surprise that the whole world all around us will change.)

This is now called 'the law of attraction'; you develop a positive mind set, you will see that positive happenings will come to you. David Hooper, (2007).

You need to accept that you are special. Every one of us is special. People need you. We can all bring about change, small or large, if we all set ourselves to it. According to Iqbal:

Ghawas-e Muhabat Ka Allah Nighaiban Ho;

Har Qatra-e Darya Mein, Darya Ki Hai Ghehrai.

(Pray for the element of love within our fellow beings, which is the basis of connectivity in the society. Every drop of water matters in the whole flow of river.)

For the development of a collective identity, Iqbal's message is: 'Be innovative, accumulate resources, and work for a healthier state. Let this be the central idea, to plan around it, and set actions for achieving the goal'.

For the moneyed class, Iqbal delivers this message:

Faiz Chahta Hai Tou Faiz Ke Saman Bana;

\section{Pul Bana Chah Bana, Masjid-o Talaab Bana.}

(If you want to be rewarded, then set yourself on rewarding others. Do whatever you can for others; for their convenience, wellbeing and integrity.) 


\subsection{Healthier People Are the Needs of the Moneyed Class to Further Generate Wealth}

The message for the moneyed class is; 'The people you serve the needs, are your 'CUSTOMERS' in a business language. Identify your customers, their characteristics, and their needs. If you hit the real needs of the people, and if you are able to demonstrate your credit worthiness, the money will come rolling'.

Un-wellness at work is incredibly costly. See Fig-2.and reference Teresa Novellino, (2016).

According to the statistics in the United States, $\$ 2.2$ trillion is the annual loss which amounts to $12 \%$ of the total GDP.

$\$ 1,100 \mathrm{~b}$ due to cost of chronic disease.

$\$ 250$ b due to work related injuries and illness.

$\$ 300 \mathrm{~b}$ due to work related stress.

$\$ 550 \mathrm{~b}$ due to cost of disengagement at work

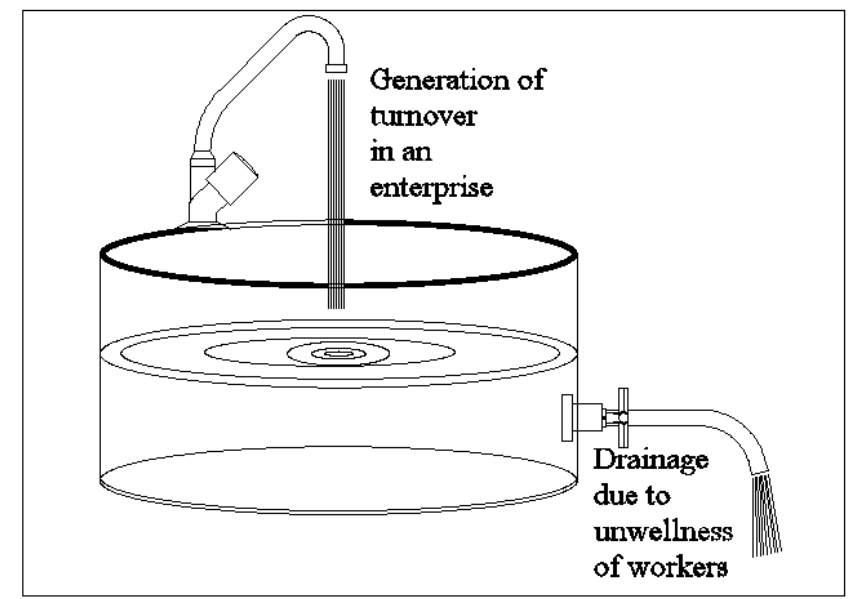

Figure 2. Losses to an Enterprise due to Unwellness of Workers

\subsection{Collective Identity - A primary Requisite for Movement towards Healthier Community}

Building a collective identity is a fundamental requirement for the success of the development projects, aimed towards achieving a healthier community. Collective identity needs to be inculcated among the stakeholders around the development projects. Once the stakeholders are set, the economics of building a healthier community is clearly made visible. Then comes the outreach. Smart digital instruments these days, have made the outreach much more convenient than it has been in the past. For action plan, then, a toolkit has been developed, which is explained below.

\section{Stakeholders}

\subsection{Who are the Stakeholders}

Stakeholders are those with any interest in your project's outcome. They are typically the members of a project team, project managers, executives, project sponsors, customers, and users.

There are four types of stakeholders (UPIGs). See Fig-3 reference Horst Hejny, Günter Tiess, Angelika. (2017).

- users,

- government,

- Influencers,

- Moneyed class and

- the Sponsors.

The stakeholders need to be brought round in a participative mechanism. Anyone can kick start and set the ball 
rolling.

At the inner circle of the possible stakeholders are the local residents, local town administration, local political leaders, local land and business owners.

At the next outer circle are community activist organizations, and the buying and selling chains who draw out resources out of your community, and pour in resources into it.

At the outermost circle, there are the know how providers, influential having roots in the area, developers and contractors who look forward to business in your area, and planners, architects and engineers.

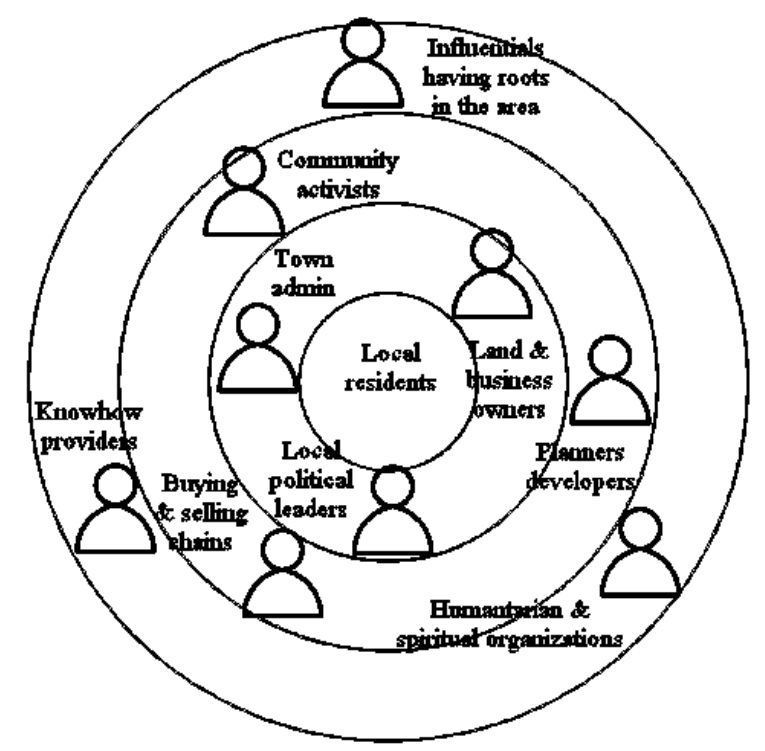

Figure 3. Identification of Stakeholders in Your Area

Jouni K. Juntunen, Minna Halme, Angelina Korsunova, and Risto Rajala, (2019) have maintained that, in carrying out projects for innovative and sustainable products, services and business models, integration with stakeholders is necessary. It creates an atmosphere of a collective identity. The strategies of their induction, as to their numbers, their types, and the stage of their induction have been studied. It has been found that deep organizational integration with the stakeholders is very necessary, for the environment of oneness.

\section{Movement towards a Healthier Community}

\subsection{Economics of Movement Towards a Healthier Community}

The fundamentals of the economics of movement towards a healthier community are:

- Movement towards healthier community is a net gain of resources flow into the community.

- It is derived from the production of resources, goods and services in excess of local consumption.

- It focuses on bringing in money from outside into inside, not just re-circulating the same money within. Nora Lustig. (2004).

\subsection{Digital Outreach Today}

The convenience with which we can reach to the people today was never there in the past. We are connected together through mobiles, internet and emails. Portals and platforms are there for our use and participations. Jessie Curell. (2012).

Remote areas are no more remote

- Online money transactions

- Online buying and selling 
- Online education, health, legal aid and e-government

- Online professional platforms for planning and engineering services

- Communication networks widely operated

- Producer - consumer culture integration

- Urban - rural linkage

- Moneyed class - worker class win-win

\subsection{Smart Healthcare System Example}

- Smart healthcare is a health service system that uses technology such as wearable devices, IoT, and mobile internet to dynamically access information, connect people, materials and institutions related to healthcare, and then actively manages and responds to medical ecosystem needs in an intelligent manner.

- In healthcare context, common uses of digital technologies include searching medical knowledge resources, facilitating clinical support, monitoring quality of care, and mapping and monitoring the spread of infectious diseases, as well as tracking supplies of drugs and vaccines. Elizabeth Carpenter. (2022).

\subsection{Proposed Action Plan Toolkit}

As per Brian H. Roberts, (2022) an action plan toolkit specifically for healthcare services for the people in a local area, can be taken up as in the following. The first stage is an information gathering stage. It is in three steps spelled out below as three questionnaires. For other sectors such as education and employability, action plans can be drawn on similar lines.

Questionnaire 1. Walk through Your Area

\begin{tabular}{|c|c|c|c|c|c|c|c|}
\hline \multicolumn{4}{|l|}{ Resources } & \multicolumn{4}{|c|}{ Stakeholders } \\
\hline \multicolumn{4}{|c|}{$\begin{array}{l}\text { What wealth production areas are affected by unwellness } \\
\text { of people. How much can convincingly be diverted to } \\
\text { wellness facilitations? }\end{array}$} & \multicolumn{4}{|c|}{$\begin{array}{l}\text { What public officials are there who can be approached } \\
\text { to join a participatory improvement effort? }\end{array}$} \\
\hline Minerals & Wheat & Milk & Garments & MPAs & Local & Teaching & Councilors \\
\hline Gems & Rice & Meat & Leather & MNAs & Admin & Institutions & \\
\hline \multirow[t]{3}{*}{ Timber } & Cotton & Goats & Shoes & & & & \\
\hline & Vegetables & Poultry & Cutlery & & & & \\
\hline & & & Handicrafts & & & & \\
\hline \multicolumn{4}{|c|}{$\begin{array}{l}\text { What facilities exist and what can be added within the } \\
\text { resources? }\end{array}$} & \multicolumn{4}{|c|}{$\begin{array}{l}\text { What private influential are there who can be } \\
\text { approached to join a participatory improvement effort? }\end{array}$} \\
\hline Wellness & Emergency & Family & Hospitals & Land & Business & Peers & Renowned \\
\hline \multirow[t]{2}{*}{ Centers } & Centers & Clinics & & Owners & Owners & Mullahs & People with \\
\hline & & & & & & NGOs & Roots \\
\hline
\end{tabular}

Questionnaire 2. Map Potentials and Impediments

\begin{tabular}{|c|c|c|c|c|c|c|c|}
\hline \multicolumn{4}{|c|}{ Growth Potentials } & \multicolumn{4}{|l|}{ Impediments } \\
\hline \multicolumn{4}{|c|}{$\begin{array}{l}\text { What existing facilitations can you possibly expand to } \\
\text { accommodate growth? }\end{array}$} & \multicolumn{4}{|c|}{ What hazards do you see in implementing the plans? } \\
\hline Add & Add Infra & Add & General & Convincing & Physical & Land & Resistance \\
\hline $\begin{array}{l}\text { Door to } \\
\text { Door }\end{array}$ & Structure & Profess-ionals & $\begin{array}{l}\text { Iprove- } \\
\text { ments }\end{array}$ & $\begin{array}{l}\text { the } \\
\text { Moneyed } \\
\text { Class }\end{array}$ & $\begin{array}{l}\text { Infra- } \\
\text { structure }\end{array}$ & Acquisition & from People \\
\hline \multicolumn{4}{|c|}{ How do you keep stakeholders involved? } & \multicolumn{4}{|c|}{ What public and official facilities do you foresee? } \\
\hline Displays & Transparent & Inviting & Review & Peoples' & Admin & Political & Capital \\
\hline $\begin{array}{l}\text { of } \\
\text { Returns }\end{array}$ & Records & Inspections & Meetings & $\begin{array}{l}\text { Ownership } \\
\text { Titles }\end{array}$ & Resistance & Resistance & Procurement \\
\hline
\end{tabular}


Questionnaire 3. Setup Digital Platform and Team

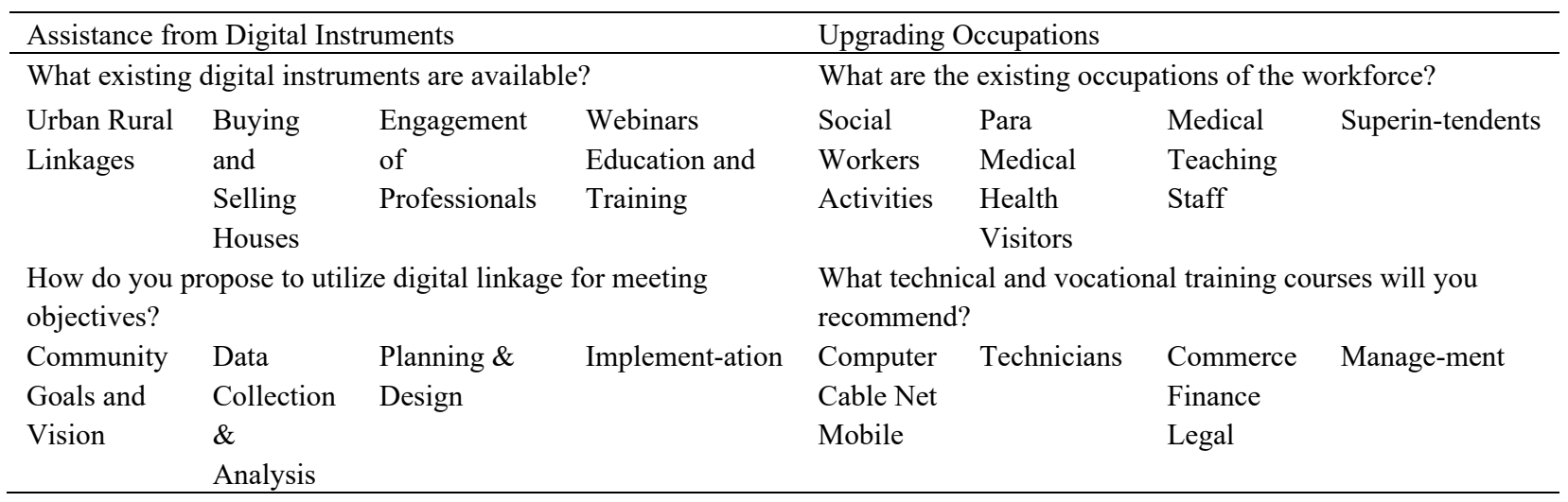

When the questionnaires are done, the further steps are:

Pondering on a societal issue in the chosen locality;

1) Walk through the area

2) Draw a physical map of the area, locating the problem, the resources, the stakeholders;

3) Make presentations for the stakeholders to win their confidence;

4) Loop in stakeholders; to bring resources in;

5) Identify growth potentials and impediments in the area; and

6) Avail the digital instruments for advocacy and teaming.

This is how the individual selves can be teamed together into a collective self. They will be ready for the societal building, taking social responsibility, and geared up to address the problems.

\section{Examples of Role of Collective Identity}

A few examples can be quoted here, where an atmosphere of collective identity's role can be studied.

\subsection{Apartments Renovation Project in Joensuu Finland}

Aki Aapaoja, Harri Haapasalo, and Pia Söderström, (2013). Aki Aapaoja have reported an Apartments Renovation Project in Joensuu Finland that was carried out on a novel method in which an atmosphere of collective self was created by adopting a relational contracting method in which the stakeholders were fully involved right at the early stage. Two interconnected four-story buildings built in 1971, one with 39 offices and the other with 19 apartments needed renovations on account of safety and energy efficiency. Instead of working on conventional stand official contracting, the project was carried out by building relationships with the stakeholders right at the early stage of its inception. The atmosphere of collective self, that it created was found advantageous in a number of ways.

(i) Better designs because of brain storming by the parties having stake in the project.

(ii) Construction operations considered during designing thereby less wastages.

(iii) Incorporation of the needs of the end users.

(iv) Matching of the specifications with the providers' abilities.

(v) Evolution of creative solutions by intensive exchange of ideas.

(vi) Synchronizing in runs and stages.

\subsection{Management of Stakeholders in Norway Projects}

Jan Terje Karlsen, (2002) has reported a survey that was conducted from project managers in Norway regarding their opinion about the stakeholders, such as: clients, end users, contractors, consultants, labor unions, line organization, public authorities, financial institutions, insurance companies, controlling organizations, media, third parties, and competitors.

The survey indicated that while the clients and the end users were the most important entities, the contractors, 
suppliers, line organizations and public authorities were trouble makers too. The management of the stakeholders was revealed as an important job. There have been identified as six steps:

1. Organizing the management process keeping in view of the purpose and the circumstances.

2. Identifying the stakeholders by interviewing them in a group of participants.

3. Assessing the stakeholders as potential threat or collaboration.

4. Communicating with the stakeholders and developing understanding with them.

5. Developing strategies as to how to deal with them.

6. Watching the relationship, and change strategies if necessary.

\subsection{Stakeholders Ethics and Employees' Spiritual Intelligence at Spiritual Workplace in US}

Tim Lowder (2006) has demonstrated that in order to maintain a level of stakeholder ethics, a program is needed to run to heighten the employees' spiritual intelligence. Such a program has positive outcomes on the organizational culture and the stakeholders' ethics. Other positive outcomes are: higher productivity, increased job satisfaction, lower turnover rates, positive ethical values, better attendance rates, and higher customer satisfaction.

What is needed to inculcate is "a strong sense of purpose, focus on individual development, trust and respect, humanistic work practices, and toleration of employee expression. These personal quality characteristics of the employees blended with the stakeholders' work ethics have strong boosting up effect on the organizational productivity. Jennifer Crocker. (1992).

\section{Conclusion}

Development of a collective identity is fundamental to any societal movement in a group or a community. The teachings of Iqbal, a poet, philosopher and spiritual leader of the days of British Rule in India, are a blue print on the basis of which a change of focus from personal selves to a collective self can be attempted. The stakeholders are the backbone of any societal intervention, and equally in a project environment. The moneyed class can be convinced that healthier people work better. Spending on their wellbeing saves them from great business losses. Outreach to people is easy these days in wake of digital instruments. A toolkit has been developed for mobilizing individual selves to a collective self, gearing towards societal projects and wellbeing interventions in a community. Examples of stakeholder mobilization and management towards building their collective identity can be referred: a construction project in Finland, the management environment in Norway, and spiritual workforce situation in the US.

\section{References}

Aapaoja, H. H., \& Pia, S. (2013). Early Stakeholder Involvement in the Project Definition Phase: Case Renovation. Hindawi Publishing Corporation ISRN Industrial Engineering, Article ID 953915. Retrieved from https://www.hindawi.com/journals/isrn/2013/953915/

Brian, H. R. (2022). Tool KIT for Rapid Economic Assessment, Planning, and Development of Cities in Asia. Asian Development Bank. Retrieved from https://www.adb.org/sites/default/files/institutional-document/161535/toolkit-rapid-economic-assessment-cities. pdf

Brown, S. (1987). Thinly Disguised Contempt - A Barrier to Excellence. PMID: 3644872, National Library of Medicine, PubMed.gov. Retrieved from https://pubmed.ncbi.nlm.nih.gov/3644872/

David, H. (2007). Law of Attraction - How to Earn Money, Love and Happiness. Kathode Ray Enterprises. Retrieved from https://theyoungtreps.com/wpcontent/uploads/2021/03/LAWS_OF_ATTRACTION.pdf

Elizabeth, C. (2022). Healthcare Industry Outlook: Advance Your Opportunity. Avalere. Retrieved from https://avalere.com/webinars/avalere-2022-healthcare-industry-outlook-advance-your-opportunity?gclid=Cj0KCQi AmKiQBhClARIsAKtSj-k_jbgjnH1C3a9VcmbjP5AOPfnUa6k7YWi8Bhp7Q2tKfXHt-fqub_EaAgFYEALw_wc B\#

Gustavo, R., Jennifer, T. C., \& Anna, C. N., (2011). Behavioral Dissociation between Exogenous and Endogenous Temporal Orienting of Attention. PLoS ONE, 6(1), e14620.

Hakeem, A. Ha. (2012). Shaheed Hakeem Muhammad. Saeed Number, Hamdard Magazine, Lahore. Retrieved from 
https://iqbalkalmati.blogspot.com/2021/10/shaheed-hakeem-muhammad-saeed-number.html

Horst, H. G., \& Tiess, A. (2017). Stakeholders Mobilization - Interim Report. Int-met Consortium. Retrieved from https://www.intmet.eu/wp-content/uploads/2018/12/D8.3.pdf

Jan, T. K. (2002). Project Stakeholder Management. Norwegian School of Management BI. Engineering Management Journal, 14(4).

Jennifer, C. (1992). A Collective Self-Esteem Scale: Self-Evaluation of One's Social Identity. Personality and Social Psychology Bulletin. Retrieved from https://www.researchgate.net/publication/258180371_A_Collective_Self-Esteem_Scale_Self-Evaluation_of_On e's_Social_Identity

Jessie, C. (2012). Digital Outreach for Community Engagement. A Digital Library Framework for Canadian Schools, Ottawa. Retrieved from https://mediasmarts.ca/sites/mediasmarts/files/lesson-plans/lesson_digital_outreach_community_engagement.pd $\mathrm{f}$

Jouni, K. J., Minna, H., Angelina, K., \& Risto, R. (2019). Strategies for Integrating Stakeholders into Sustainability Innovation: A Configurational Perspective. Journal of Product Innovation Management. Retrieved from https://www.researchgate.net/publication/328616896_Strategies_for_Integrating_Stakeholders_into_Sustainabil ity_Innovation_A_Configurational_Perspective

Kevin, D. K., \& Simon, R. (1987). Tender Loving Care - A Relational Ethics in Nursing Practice. National Library of Medicine, PubMed.gov. Retrieved from https://pubmed.ncbi.nlm.nih.gov/12035434/

Meg, G. (2004). Mother Teresa. Green Wood Biographies. Retrieved from https://ati.dae.gov.in/ati12052021_3.pdf.

Nora, L. (2004). Investing in Health for Economic Development. First edition, Universidad de las Américas, Puebla Santa Catarina Mártir, Cholula, 72820 Puebla, México. Retrieved from https://www.who.int/macrohealth/action/sintesis15novingles.pdf

Rachel, D., Annette, P. D., Jan, H., \& Lalage, D. S. (2012). The challenge of defining wellbeing. International Journal of Wellbeing, 2(3), Cardiff Metropolitan University. Retrieved from https://www.researchgate.net/publication/233740458_The_challenge_of_defining_wellbeing

Reem, R., Kris, H., \& Patrice, M. (2016). More than Just Doing Good, A Definition of Change Maker. Retrieved from https://www.evansville.edu/changemaker/downloads/more-than-simply-doing-good-defining-changemaker.pdf

Reynold, N. (1920). Asrar e Khudi. Allama Iqbal.com. Retrieved from $\mathrm{http} / /$ www.allamaiqbal.com/works/poetry/persian/asrar/translation/index.htm

Sara, R. (2019). Allama Iqbal Role in Creation of Pakistan. Iqra University, Karachi. Retrieved from https://www.researchgate.net/publication/334041368_Allama_Iqbal-Mufakir_e_Pakistan

Shayari, U. (2018). Read Allama Iqbal Poetry/Roman Urdu \& English Translations. Largest Poems \& Ghazals Collection of Kalam-e-Iqbal. from https://sur.ly/o/iqbalurdu.blogspot.com/AA000014?pageviewId=desktop302e3531333338353030203136343438 34333135342031303330313834393531

Tajfel, H., \& Turner, J. C. (2004). The Social Identity Theory of Intergroup Behavior. In J. T. Jost \& J. Sidanius (Eds.), Political psychology: Key readings (pp. 276-293). Psychology Press. Retrieved from https://psycnet.apa.org/record/2004-13697-016

Teresa, N. (2016). Unwellness at Work Costs US \$2.2 trillion, Report Finds. Upstart Business Journal, New York. Retrieved from https://www.bizjournals.com/newyork/news/2016/02/18/non-wellness-at-work-costs-u-s-2-2-trillion-report.html

Textor, C. (2022). Annual per capita disposable income of rural and urban households in China from 1990 to 2021. Statista.

Retrieved

from https://www.statista.com/statistics/259451/annual-per-capita-disposable-income-of-rural-and-urban-householdsin-china/

Tim, L. (2006). New Dimensions of Corporate Culture: A Construct for Stakeholder Ethics in a Spiritual Workplace. Capella University, Ethics and Social Responsibility. Retrieved from 
https://papers.ssrn.com/sol3/papers.cfm?abstract_id=916740

Usama, K., \& Abdul, S. E. (2016). The philanthropist who filled in for the state in Pakistan. South@Asia, Lahore School of Economics. Retrieved from https://www.researchgate.net/publication/334041368_Allama_Iqbal-Mufakir_e_Pakistan

Wikipedia, J. (2022). Welfare State in the United Kingdom. Retrieved from https://en.wikipedia.org/wiki/Welfare_state_in_the_United_Kingdom

Wisman, J. (2018). Exploitation, Human Nature and Social Institutions. American University Working papers Series, Washington DC. Retrieved from https://www.researchgate.net/publication/323428546_Exploitation_Human_Nature_and_Social_Institutions

Zafar, I. (2004). Allama Iqbal's Concept of Khudi. Pakistan Link. Lahore. Retrieved from https://pakistanlink.org/Opinion/2009/July09/10/02.HTM

\section{Copyrights}

Copyright for this article is retained by the author(s), with first publication rights granted to the journal.

This is an open-access article distributed under the terms and conditions of the Creative Commons Attribution license (http://creativecommons.org/licenses/by/4.0/). 